\title{
Towards configuring the neolithisation of Aegean Turkey
}

\author{
Çiler Çilingiroğlu ', Canan Çakırlar² \\ 1 Department of Protohistory and Near Eastern Archaeology, Ege University, Bornova-Izmir, TR \\ cilingirogluciler@hotmail.com \\ 2 Groningen Institute of Archaeology, Groningen University, Groningen, NL \\ c.cakirlar@rug.nl
}

\begin{abstract}
Increasing field work in the Izmir region has produced much sought tangible evidence about the ways in which food-producing communities emerged in the Aegean. Focusing on the archaeological and zooarchaeological data from Ulucak and neighboring sites, the authors discuss the possible mechanisms of initial farmer-herder dispersals into the region. The authors stress that the lack of pre-Neolithic strata in the eastern Aegean impedes a full understanding of forager-farmer interactions in the early Holocene.
\end{abstract}

IZVLEČEK - Intenzivno terensko delo na območju Izmirja je prineslo težko pričakovane oprijemlive dokaze o tem, kako so se v Egeji pojavile skupnosti, ki so proizvajale hrano. V članku predstavljava možne mehanizme, ki so jih uporabili prvi poljedelci - pastirji pri širitvi na tem območju, pri tem pa se osredotočava na arheološke in zoo-arheološke podatke iz Ulucaka in sosednjih regij. Pomanjkanje predneolitskih plasti na območju vzhodne Egeje ovira popolno razumevanje odnosov med lovci in nabiralci na eni in poljedelci na drugi strani v času zgodnjega holocena.

KEY WORDS - emergence of farmer-herders; Neolithic Aegean; West Turkey; leap-frog colonisation model

\section{Introduction}

Recent ongoing research in Aegean Turkey has led to major progress on the emergence and development of early farming societies. A true terra incognita for Neolithic studies until the mid-1990s, the region is enjoying new archaeological investigations of its preBronze Age heritage. Until very recently, the absence of systematic research on Neolithic cultures in this area prevented scholars focusing on neolithization of the Aegean and Southeastern Europe from basing their models on solid archaeological evidence. As a result, Aegean Turkey emerged as a missing link in discussions of the origins and development of the Neolithic way of life. Since the mid-1990s, systematic excavations have been opened at several mounds in the area containing cultural deposits dating to the $7^{\text {th to }}$ early $6^{\text {th }}$ millennia BC (Fig. 1). Besides Ulucak, research at the Yeşilova and Çukuriçi mounds are continuing (Derin 2012; Horejs 2012), whereas the field work at Ege Gübre and Dedecik Heybelitepe has ended (Herling et al. 2008; Sağlamtimur 2012).

The longest stratigraphic sequence, found at Ulucak, extends from the first half of the $7^{\text {th }}$ to the early $6^{\text {th }}$ millennium BC (Çilingiroğlu et al. 2004; Çilingiro $\breve{g-}$ lu, Cilingiroğlu 2007; Cilingiroğlu et al. 2012). Radiocarbon dates from Ulucak's Level VI have demonstrated that the earliest farmers appeared in the region between 7000-6600 calBC. Having domestic livestock and plants (Cakirlar 2012a; 2012b; Cilingiroğlu et al. 2012.150), but no pottery, this community erected buildings with elaborate plaster floors. Current archaeological data indicate that food-producing sedentary communities did not arise independently in this area. 


\section{The Pre-Neolithic background in West Turkey}

More satisfying answers on the neolithization processes in the region can only be formulated with problem-oriented research on the pre-Neolithic background. Any discussion on the neolithization of a given geographical unit should involve pre-Neolithic culture history of the region. Unfortunately, as extensive and intensive surveys focusing on pre-Neolithic ages are absent around İzmir, our knowledge on pre-Neolithic communities is confined to very limited data. Pre-Neolithic finds from the area are confined to two hand-axes of Lower Paleolithic type found in Urla and Narlıdere in the İzmir

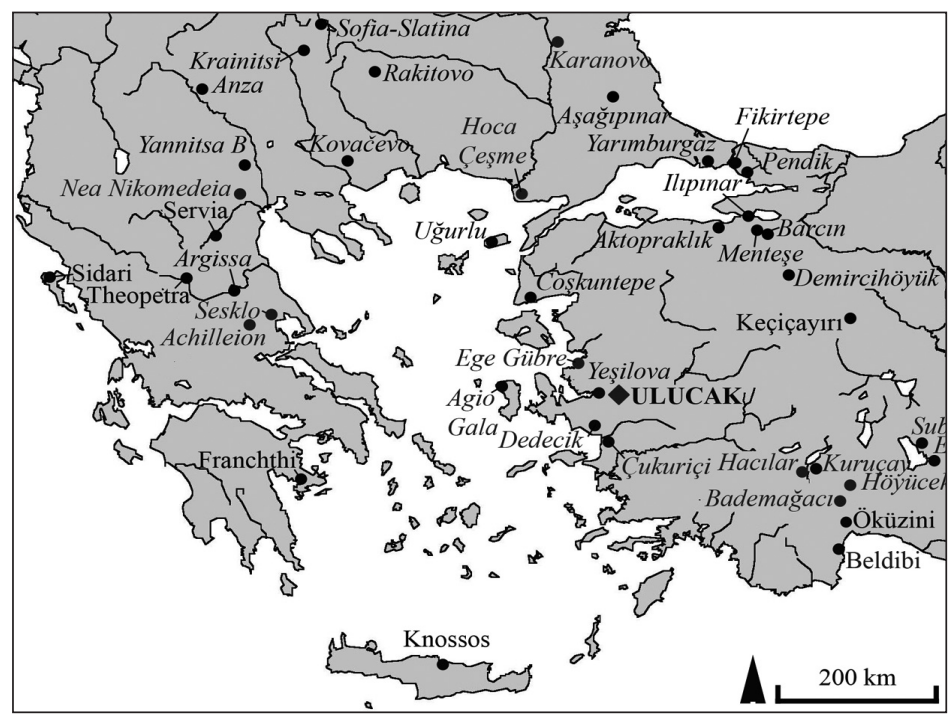

Fig. 1. Sites mentioned in the text. province (Kansu 1963; 1969). Recently, an open-air site east of Izmir, in Manisa province, is discovered by the Central Lydian Archaeological Survey (CLAS) of Boston University. The open-air site, called Bozyer, produced material mainly from the Lower Paleolithic era (Roosevelt, Luke 2010). About the early Holocene foragers we simply lack any sort of information.

The best investigated Epi-paleolithic findspots in Turkey are the Öküzini and Karain Caves on the southern coast near Antalya and Pınarbaşı B rock shelter in Konya. In the western Aegean, Franchthi Cave provides a reliable sequence from $c .11000$ to $7000 \mathrm{BC}$ and there is promising new research. Below we will provide a glimpse at the general characteristics of these sites.

At Karain Chamber B and Öküzini's earlier Epi-paleolithic deposits, the chipped stones are characterized by non-geometric microliths. The quantity of geometric microliths shows a sudden increase at Öküzini after $c .13000 \mathrm{BC}$. The archaeological units I to IV at Öküzini contain remains contemporary to Kebaran and Natufian periods in the Levant. The chipped stones assemblage is typically characterized by lunates, triangles, trapezes, retouched bladelets and backed blades (Kartal 2003.39-40; 2009.158-159). Unit II, dated to $14000-13000 \mathrm{BC}$, contained grinding slabs, hammer-stones, marine shell ornaments produced from Dentalium, Columbella rustica and Arcularia gibossula. Unit III, dated to $c .13000-$ $10500 \mathrm{BC}$, is rich in bone industry such as awls, needles and spatulas. Several incised pebbles are also attributed to this phase (Otte et al. 1995.941). The community hunted mainly wild ovicaprines and fallow deer (Atıct 2011) and collected nuts, bulbs, roots and tubers (Martinoli 2004). The occurrence of grinding implements at Öküzini's later Epi-paleolithic strata as well as the nature of the plant remains suggest that the site was occupied for longer periods and plant processing was a crucial subsistence activity at this stage (Otte el al. 1995.937-941; Martinoli 2004).

Looking at the the western Aegean, there is new research producing much sought evidence on the Early Holocene foragers (Sampson 2005; Strasser et al. 2010; Reingruber 2011.296). Yet the best sequence of events encompassing the time period in question still comes from the Franchthi Cave in southern Argolid. The Final Paleolithic stratum at the cave is characterized by microliths and micro-burins which constitute the $75 \%$ of the chipped stones (Perlès 2001 . 31). The Early, Late and Final Mesolithic phases (c. 9000-7000 BC) at the cave show very different features in terms of material culture from Öküzini, P1narbaşı B rock shelter and Natufian sites. Microliths and micro-burin technique disappear in the Early Mesolithic and, although the microliths re-appear around $8000-7500 \mathrm{BC}$, they are now produced on flakes and are non-geometric in shape. Around 7000 BC, crude flake tools and few arrowheads constitute the assemblage. In contrast to Natufian sites and Öküzini, grinding implements are very rare at Franchthi Cave (Perlès 2001.34). It seems like although the Franchthi community used the marine environment for fishing and obsidian procurement, most probably navigating with reed-bundle crafts (Perlès 2001.36), range of their social world did not expand much beyond the Aegean.

Such findspots containing pre-Neolithic sub-stratum of İzmir Region is virtually unknown due to lack of 
research. One can not help but wonder whether eastern Aegean early Holocene foragers were more engaged in relations with Anatolian or western Aegean social spheres. Alternatively, should we expect Aegean and Anatolian early Holocene components to merge and create something entirely different in West Turkey? As a result, further research is needed in the area to understand the nature of pre-Neolithic communities. Until more archaeological evidence is available, our questions regarding local foragers and their possible interactions with farming communities cannot be adequately addressed.

\section{Ulucak VI and the first farmer-herders of Izmir region}

Level VI at Ulucak contains the earliest archaeological record of early farmers in Aegean Turkey and encompasses the earliest occupation level on the mound. The occupation is dated to the first half of the $7^{\text {th }}$ millennium BC in absolute terms. AMS determinations from this occupation level provide a calibrated range of 7040-6470 BC. Dates obtained on shortlived species from Ulucak VI provide ranges from 6690 to 6590 calBC at one sigma (Çilingiroğlu et al. 2012.153). The data from Level VI are preliminary, but are potentially the first recorded instance of early farmers in eastern Aegean and offer a new insight into the spread and development of Neolithic culture in western Turkey and the Aegean.

The most striking characteristic of this occupation level is the presence of red-painted plaster floors. Such floors are attested in two separate buildings, the older No. 43 and the younger No. 42 (Fig. 2). Besides

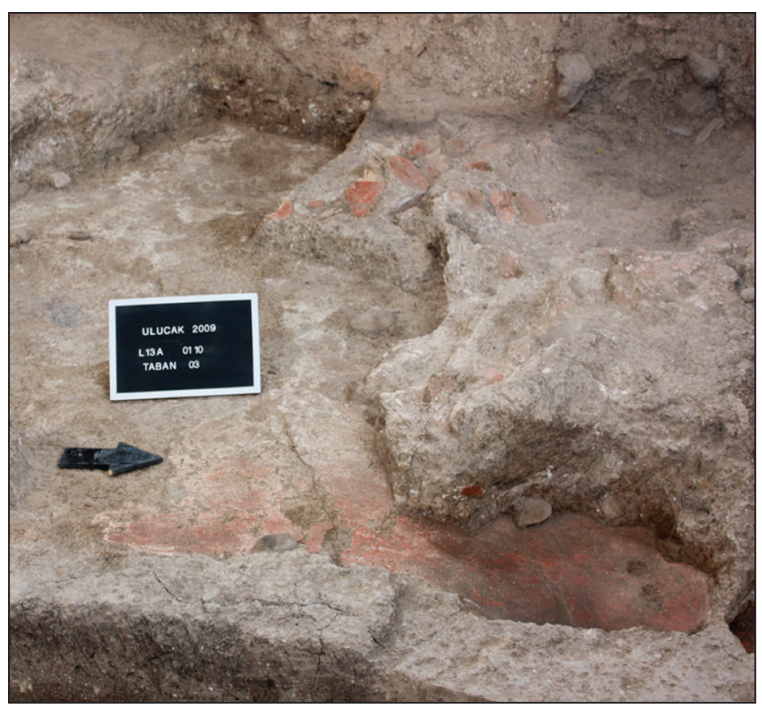

Fig. 2. Building 42 with red plastered floor (Level VI, c. 6700-6600 BC). these buildings, Level VI is comprised of open areas with cobblestone paving and circular hearths, typically surrounded by ashy deposits including large amounts of animal bone and plant remains (Çevik 2013.148-150).

Another interesting aspect of Level VI is the lack of typical Neolithic components of the material culture known from the Aegean and Southeast Europe such as figurines, sling missiles, polished axes and clay stamps. So far, neither pottery nor clay objects have been found in these deposists, which are approximately one metre deep. The pottery, which decreases in quantity throughout Level $\mathrm{V}$, disappears completely with Level VI. Considering the good quality of the earliest pottery at the site, the introduction of pottery to the site seems to have been rather abrupt, at around $6400 \mathrm{calBC}$. Even if future research reveals clay containers from this level, it is clear that in the first half of the seventh millennium $\mathrm{BC}$, containers and objects from fired clay did not have a significant function in the daily lives of these farmers. Stamps, figurines, clay weights or sling missiles, all very commonly found in the later levels IV-V, are completely absent from the Level VI assemblage so far. In fact, the material culture comprises very few elements in comparison to the upper occupation levels. Used and worked bone at various production stages is the most common artefact category beside chipped stones. Blank splinters, points, ad-hoc tools, awls, and gauges made of sheep and goat bones occur frequently. The bone tool-kit of both formal and informal tools has affinities with the Çatalhöyük bone tool assemblage (Russell 2006; but note that this is the only intensively studied Neolithic bone tool assemblage in Turkey). Interestingly, in Level VI, the quantity of marine molluscs is minute and the quantity of obsidian recovered is exceptionally small, which is again in sharp contrast with levels $V$ and IV.

As mentioned above, the Ulucak VI community subsisted on farming and herding. The preliminary results of macrobotanical research indicate that the community cultivated a variety of cereals and pulses, the main crops being einkorn wheat (Triticum monococcum), emmer wheat (Triticum turgidum ssp. dicoccon), barley (Hordeum sp.), durum wheat (Triticum aestivum/durum) and free-threshing wheat (Cilingiroğlu et al. 2012.150). Archaeozoological investigations show that domestic ungulates including sheep, goat, cattle and pig constitute the large majority of the animal bone assemblage (Cakirlar 2012a). While ancient DNA research traces the origins of domestic ruminants in Ulucak to lineages in Southwest 
Asia (Scheu et al. 2012; in prep.), the same line of evidence indicates that the domestic pigs of Ulucak derive from a western Anatolian haplotype that may have resulted from the interbreeding of local wild boar and Southwest Asian domesticated pigs (Otto$n i$ et al. 2013). This specific western Anatolian haplotype was ancestral to the earliest domesticated pig populations in Europe (Ottoni et al. 2013). Demographic patterns of sheep and goat populations present no strong evidence for dairy production in this phase of Neolithic occupation at Ulucak (Cakırlar $2012 b$ ). The role of wild animals in subsistence appears to have been very limited. Deer, especially fallow deer (Dama dama) prevail among the targeted wild animals, whereas small game such as the European hare (Lepus europaeus) is present, but rare. On the whole, both agriculture and herding seem to have been at a well-established stage and the dominant form in Ulucak VI. The four-tiered herding system at Ulucak at the beginning of the 7 th millennium $\mathrm{BC}$ has been evidenced only at Bademağacı in the Lake District (De Cupere et al. 2008) and in the 'Aceramic Neolithic' in Knossos on Crete (Isaakidou 2008) among its contemporaries in the entire AegeanAnatolian region.

The community that founded the basal occupation at Ulucak had fully mastered plaster floor technology. Ulucak's red plaster floors are technologically and conceptually well-matched with the other Anatolian examples at basal Hacılar, Aşıklı and Musular (Özbasaran 2003). Earlier examples of red plaster floors are also very well known from Levantine and Syrian PPNB sites such as Halula and Ain Ghazal (Garfinkel 1987; Bentur et al. 1991). It is clear that the idea and practice of painted plaster floors were transmitted over many generations in Neolithic southwest Asia. Considering the vast spatio-temporal distribution of this technology, the appearance of red plaster floors in Ulucak's earliest occupation level cannot be viewed as a mere coincidence and a local invention. It rather seems to be a technology and ritual practice introduced to the region from outside. This observation alone, however, does not suffice to understand how this process took place.

The important question of whether local hunter-gatherers had adopted food producing together with various technologies like plaster flooring as a result of interaction with farmers from the east (a frontier mobility model), or whether new farming communities entered the region and brought all the components characterising a food-producing economy has not been fully answered. In the frontier mobility mo- del, farmers and foragers come into contact while using established social mechanisms and trade networks. In this model, very small-scale population movement is expected (Zvelebil 2001.2). We hold that the current evidence from Ulucak supports a leap-frog colonisation model rather than a frontier mobility model.

The so-called 'leap-frog colonisation' model described by Marek Zvelebil (2001.2) stands out as one of the major demographic mechanisms for the Neolithisation of Western Turkey. This model suggests that small groups of people search for ideal habitats that would support their populations while leaving some stretches of land unsettled. New communities founded the settlement following an initial examination of the targeted land and its resources. These communities may enter areas where other populations such as mobile foragers are already present. The interaction among these groups may result in mutual or assimilative relations. In the case of mutual interaction, various exchanges of raw materials, food or other objects may take place. Intermarriages are likewise possible. These interactions may eventually result in the assimilation of one of the groups. Foragers may decide to adopt a farming way of life or farmers become foragers. If conflict arises over local resources, it continues until one of the groups may decide to retreat or even abandon the area. Taking the current information provided by Ulucak VI, it seems plausible that the community initially settling at Ulucak might have originated from Inner-West Anatolia and moved along the east-west oriented Gediz Basin seeking suitable natural habitats for farming and herding, thereby bringing a variety of new technologies and practices such as the plaster floors, animal herding and farming.

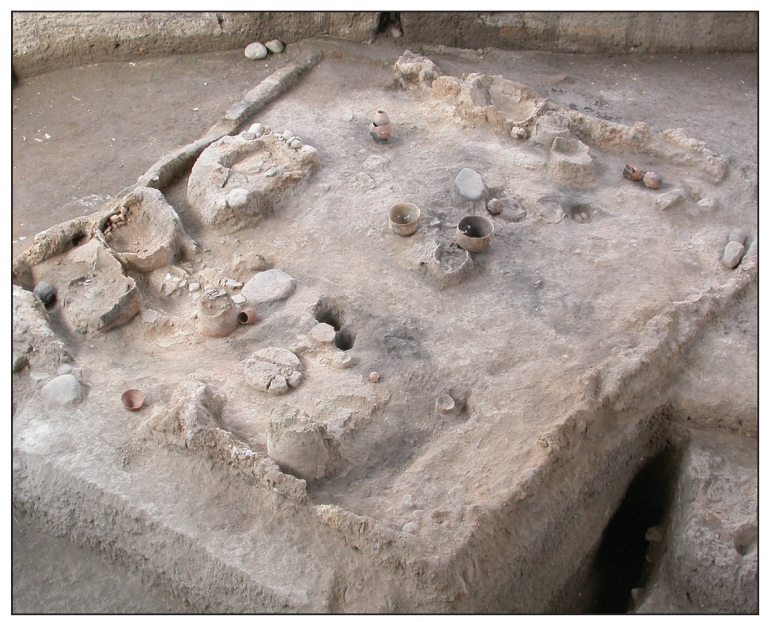

Fig. 3. Wattle-and-daub building 30 from Ulucak $\mathrm{Vb}(\mathrm{c} .6200-6100 \mathrm{BC})$. 


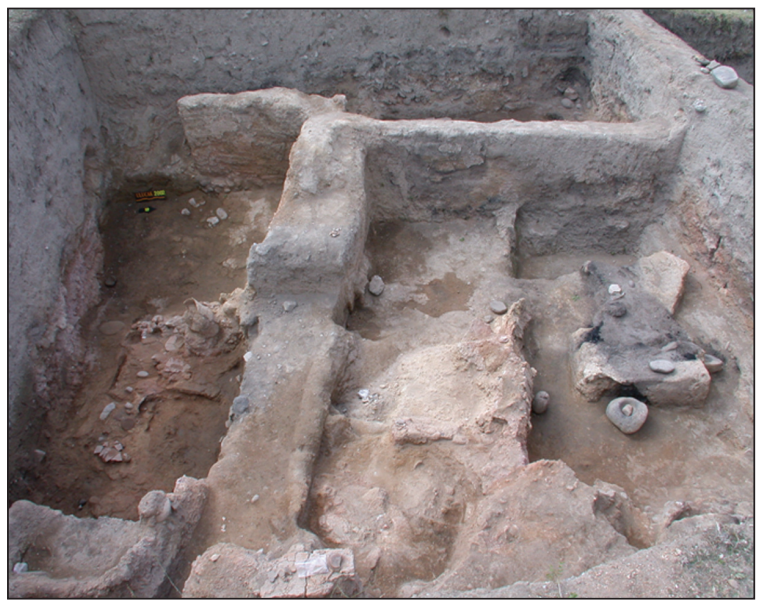

Fig. 4. Mud brick buildings 12 and 13 from Ulucak IVb (c. 5700- $5600 \mathrm{BC}$ ).

As mentioned above, it remains unknown whether mobile forager populations existed before the appearance of the first sedentary food-producing villages in the Izmir region, nor to what extent the local foragers interacted with, and contributed to, the sedentary farming way of life. Conclusive answers on Neolithisation in the İzmir region can be gained only through firm archaeological data on early Holocene forager populations.

\section{The local development of Neolithic culture}

Following the basal layers at Ulucak, we observe a continuous development of village life based on farming and herding on the mound. Single-roomed, free-standing wattle-and-daub houses with storage facilities, ovens and food preparation areas are eventually replaced by more substantially built mud-brick houses with occasional courtyards (Figs. 3-4). At Ulucak Levels V and IV, material culture consists of elements familiar from other contemporary sites in Turkey, Southwest Asia and Southeast Europe, such as clay stamps, prismatic blade cores, slings, bone spatulas, polished axes etc. (Çilingiroğlu 2005; Özdogan 2011). The same elements are observed in the region at other contemporary sites at Ege Gübre, Yeşilova and Çukuriçi (Sağlamtimur 2012; Derin 2012; Horejs 2012). The homogeneous elements in material culture reflect close social-cultural ties on a supraregional basis with both the inner Anatolian and Aegean communities. For instance, an obsidian network was sustained through centuries in the Aegean. Both eastern and western Neolithic communities had constant access to this important raw material. The transportation and distribution of Melian obsidian inevitably brought diverse people together and spurred cultural interactions. The appearance of impres- sed pottery around $6000 \mathrm{BC}$ is yet another clue to the maritime connections between Aegean and Eastern Mediterranean people. Displaying an apparent coastal distribution, the practice of impressing pots with certain designs and techniques can be observed as a common phenomenon in the Aegean during the late $7^{\text {th }}$ - early $6^{\text {th }}$ millennia BC (Cilingiroglu 2010).

The near absence of painted pottery and dominance of red-slipped and burnished pottery is distinctive of the region (Fig. 5). Observed at all sites in great quantity and ever increasing manner from mid-7th to the early $6^{\text {th }}$ millennium $\mathrm{BC}$, this ware group constitutes one of the most important local elements that distinguish the area from neighbouring regions where red-on-cream painted pottery is the defining pottery characteristic of early $6^{\text {th }}$ millennium BC sites. In the İzmir region, painted pottery does not emerge as a defining feature at all. The few painted pieces identified in the assemblages do not amount to a strong tradition of painted pottery production. The İmir communities did not choose to decorate their pots with painted designs. Other local features appear in the region through time. Vertically placed tubular lugs and thick flattened rims are very typical of the pots of the region (Cilingiroğlu 2012). A locally emergent character of West Anatolian sites can be grasped in many different aspects of the archaeological data.

Despite strong correlations between the material cultures of the İzmir region sites, these contemporary sites are also diverse. Circular architecture at Ege Gübre, a coastal settlement north of İzmir, is one of the most striking elements that contrast with the rectangular mud-based architecture of Ulucak and Yeşilova. The tholos-like structures or a combination of rectangular and circular architectural elements at Ege Gübre have no parallels inside the region. The function of these buildings, i.e. whether they are storage buildings or normal houses, is disputed. However, the fact that no hearths or ovens have been discovered inside the circular structures may indicate

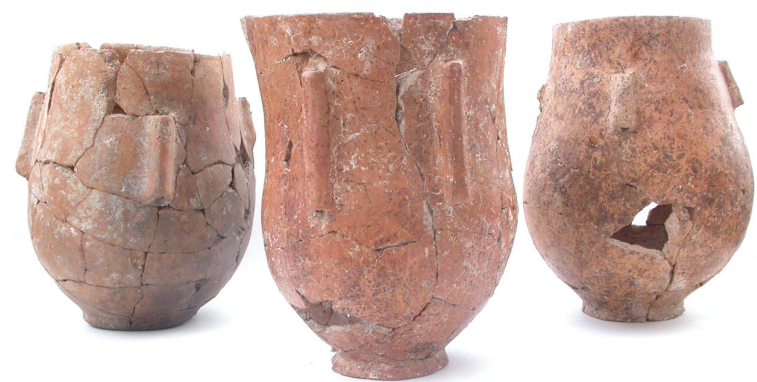

Fig. 5. Plain burnished vessels from Ulucak Vb (c. 6200-6100 BC). 
that they were not domestic dwellings (Sağlamtimur 2007.374; Fig. 5).

The house architecture at Ulucak and Yeșilova, rectilinear in plan at both sites, also reveals notable differences in building techniques. At Ulucak IV, the houses are built on a single row of stone foundations with standard-size, sun-dried and moulded mud bricks (Çilingiroğlu, Cilingiroğlu 2007.364). However, mud bricks are not found at the contemporary site at Yeşilova Late III. The houses have thick stone foundations and hand-shaped mud blocks, occasionally supported by wooden beams. The roof is carried by wooden posts placed inside the houses instead of the walls (Derin 2010.317; Derin 2013 personal communication). Such diverse architectural characteristics are functions of both local environmental conditions and cultural preferences. Apparently, every community and village created and sustained local characteristics in several aspects of daily life, although socially and culturally all communities were strongly bonded. Future research will create a better understanding of the locally developed Neolithic culture.

In the later phases of Neolithic occupation at Ulucak, subsistence continued to rely heavily on domestic technologies. Analyses of relative abundances indicate that pork gained importance in the meat supply (Cakırlar 2012a). Hunting activities became more frequent, while hare became an important target species alongside fallow deer. Marine resources, primarily molluscs, were brought to the site fresh, particularly from lagoonal and estuariane environments, presumably located in İmir Bay. The empty shells of marine molluscs were secondarily used to make perforated objects. Inshore fish species such as gilthead sea bream (Sparus aurata) has been attested in both the hand-collected and sieved samples. Husbandry strategies changed significantly towards the end of Level $\mathrm{V}$, most plausibly to integrate dairy and possibly fleece/wool production into the economy (Cakırlar 2012b). Although compatible archaeozoological datasets from the larger region are difficult to come by, developments in subsistence during Ulucak's later levels seem to accord well with patterns observed at contemporary sites (De Cupere et al. 2008; Galik, Horejs 2011). Although the role of aquatic foraging differed with the site locations in relation to the coast, the similarity between the species compositions of the mollusc shell assemblages of coastal sites and that of inland Ulucak's is noteworthy (Galik, Horejs 2011; Sağlamtimur 2011; Derin 2012).

\section{Concluding Remarks}

Clues to the initial Neolithisation processes in Aegean Turkey have so far been found only in Ulucak's oldest occupational level VI. Dating in absolute terms to the first half of the $7^{\text {th }}$ millennium calBC, Ulucak VI encompasses the oldest remains of a Neolithic village in Aegean Turkey and, together with Knossos X, is one of the oldest in the entire Aegean.

Recent preliminary studies indicate that the founder community was in possession of domesticated plants and animals. The precise spot where the mound is located was selected for its proximity to fertile agricultural land, fresh water and woodland. With domestic livestock and cereals as the basis of their survival, they created buildings with elaborately painted plaster floors. Outside these buildings, they laid out stone-paved hearths and fire installations where food was prepared and consumed. The early settlers might not have had the best of worlds. The archaeozoological assemblage shows traces of excessive intentional fragmentation, indicating time spent acquiring nutritious substances such as marrow or fat, even from the tiniest of body parts (Cakurlar 2012a). The material culture was probably composed mainly of organic materials. The archaeological remains are very few and limited in variability. Pottery is non-existent; bone objects, lithics, circular beads and grindstones constitute the material culture from this level.

Who were the earliest settlers at Ulucak? Where did they originate? These questions have no clear answers. As mentioned above, without any firm knowledge of the local foragers, the full range of possibilities cannot be explored. In any case, we have to be open-minded about human, animal and plant dispersals along both land and maritime routes. If we rely solely on the evidence from Ulucak VI, the local emergence of food producing is not evident. On the contrary, the community was fully equipped with all the techniques and knowledge required for subsistence based on farming and herding. The set of characteristics that this type of farming presents is so far unique to western Anatolian communities (Bademağacı and Ulucak) in early 7 th millennium Turkey. Due to the delayed adoption of cattle and pigs, the four-tiered animal husbandry system does not become evident in Central Anatolia until the middle of

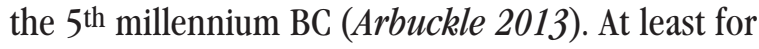
the dispersal of domestic herds, a littoral route must have been used. The appearance of red plaster floors at Ulucak VI is a cultural and, perhaps, a ritual practice that can be associated with some very early Neo- 
lithic sites in Inner-West Anatolia, Cappadocia and the Levant. The transfer of this technology and practice through time and space demonstrates its ritual character and may give us clues about the origins of the Ulucak community.

Recent excavations in Aegean Turkey have discovered locally developed Neolithic cultures with strong ties to Anatolian and Aegean communities. The local character of these communities is visible in various aspects of the material culture. The predominance of red-slipped and burnished wares as opposed to painted pottery in Aegean Turkey emerges as one of the most distinctive characteristics of the locally shaped Neolithic culture. Local features identified in the material record, however, should in no way be understood as reflecting the insular character of this area. Strong interactions with extra-local communities, such as via obsidian exchange, resulted in the cultural relatedness of these societies with those of the contemporary Aegean and Inner-West Anatolia. The similarity of the settlement patterns, subsistence, architectural techniques and material culture in this entire region is a clear manifestation of the close interactions among early farmer-herders. Land routes, river valleys and maritime routes across Anatolia, Ae- gean and Eastern Mediterranean were heavily used by prehistoric communities. The long-term circulation of Melian obsidian, the colonisation of the islands of Crete, Gökçeada (Imbros), Cyprus and the simultaneous appearance of impressed pottery around 6100-6000 calBC are clear signs of the continuous and intensive use of maritime routes across the Eastern Mediterranean and the Aegean. Considering the current state of the archaeological record, Aegean Turkey as a geographical unit is encircled by a dual interaction zone comprising the Inner Anatolian and West Aegean cultural spheres. As such, Aegean Turkey also played a key role in the mutual exchange of cultural features between Inner Anatolia and Greece.

\section{ACKNOWLEDGEMENTS}

The archaeological work at Ulucak is directed by Özlem Cevik (University of Thrace) and supported by the Turkish Ministry of Culture and Tourism, Turkish Scientific Council (TÜBITAK) and Institute of Aegean Prehistory (INSTAP). Research on the archaeozoological remains from Ulucak VI was enabled by generous funds from the Institute of Aegean Prehistory (INSTAP) and Belgian Science Policy (BELSPO).

\section{References}

Arbuckle B. 2013. The late adoption of cattle and pig husbandry in Neolithic Central Turkey. Journal of Archaeological Science 40: 1805-1815.

Atici L. 2011. Before the Revolution: Epipalaeolithic Subsistence in the Western Taurus Mountatins, Turkey. BAR IS 2251. Archaeopress. Oxford.

Bentur A., Ronen A. and Soroka I. 1991. A Plastered Floor from the Neolithic Village Yiftahel (Israel). Paléorient 17 (2): 149-155.

Baird D. 2012. Pınarbaşı, From Epi-Paleolithic Camp-Site to Sedentarising Village in Central Anatolia. In M. Özdoğan, N. Başgelen (eds.), Neolithic in Turkey: New Excavations and New Research. Arkeoloji ve Sanat Yayınları. İstanbul: 181-218.

Baysal E. 2013. Epi-paleolithic marine shell beads at Pinarbaşı, Central Anatolia from an Eastern Mediterranean Perspective. Anatolica 39: 261-276.
Çakirlar C. 2012a. Evolution of animal husbandry in Neolithic Central-West Anatolia, the archaeozoological record from Ulucak Höyük (ca. 7040-5660 cal. BC, Izmir, Turkey). Anatolian Studies 62(1): 1-33.

2012b. Neolithic Dairy Technology at the EuropeanAnatolian Frontier: Implications of Archaeozoological Evidence from Ulucak Höyük, İmir, Turkey, ca. 70005700 cal. BC. Anthropozoologica 47(2): 79-100.

Çevik Ö. 2013. Ulucak Höyük 2009-2011 y1lı kazı çalışmaları. Kazı Sonuçları Toplantısı 34: 143-158.

Çilingiroğlu A., Derin Z., Abay E., Sağlamtimur H. and Kayan I. 2004 Ulucak Höyük: Excavations Conducted Between 1995 and 2002, Ancient Near Eastern Studies, Supplement 15. Peeters. Louvain.

Çilingiroğlu A., Çilingiroğlu Ç. 2007. Ulucak. In M. Özdoğan, N. Başgelen (eds.), Türkiye'de Neolitik Dönem. Yeni kazılar, yeni bulgular. Arkeoloji ve Sanat Yayınları. İstanbul: 361-372. 
Çilingiroğlu A., Çevik Ö. and Çilingiroğlu C.. 2012. Towards Understanding the Early Farming Communities of CentralWestern Anatolia: Contribution of Ulucak. In M. Özdoğan, N. Başgelen (eds.), Neolithic in Turkey: New Excavations and New Research. Arkeoloji ve Sanat Yayınları. İstanbul: 139-175.

Çilingiroğlu C.. 2005. The Concept of 'Neolithic Package'. Considering its Meaning and Applicability. Documenta Praehistorica 32: 1-13.

2010. Appearence of Neolithic Impressed Pottery in Aegean and its Implications for Maritime Networks in the Eastern Mediterranean. Türkiye Bilimler Akademisi Arkeoloji Dergisi 13: 9-22.

2012. The Neolithic Pottery of Ulucak in Aegean Turkey: Organization of production, interregional comparisons and relative chronology. BAR IS 2426. Archaeopress. Oxford.

De Cupere B., Duru R. and Umurtak G. 2008. Animal husbandry at the Early Neolithic to Early Bronze Age site of Bademağacı (Antalya province, SW Turkey): evidence from the faunal remains. In E. Vila, L. Gourichon, A. Choyke and H. Buitenhuis (eds.), Zooarchaeology of the Near East 8. Proceedings of the Eighth International Symposium on the Zooarchaeology of Southwestern Asia and Adjacent Areas. Archéorient, Maison de l'Orient et de la Méditerranée. Lyon: 367-405.

Derin Z. 2007. Yeşilova Höyügü̈. In M. Özdoğan, N. Başgelen (eds.), Türkiye'de Neolitik Dönem Yeni Kazılar, Yeni Bulgular. Arkeoloji ve Sanat Yayınları. İstanbul: 377384.

2010. İzmir-Yeşilova Höyüğü 2009 Yılı Kazı Çalışmaları. 32. Kazı Sonucları Toplantısi: 315-323.

2012. Yeşilova Höyük. In M. Özdoğan, N. Başgelen (eds.), Neolithic in Turkey: New Excavations and New Research. Arkeoloji ve Sanat Yayınları. Istanbul: 177195.

Galik A., Horejs B. 2011. Çukuriçi Höyük - Various aspects of its earliest settlement phase. In R. Krauß (ed.), Beginnings... new research in the appearance of the Neolithic between Northwestern Anatolia and the Carpathian Basin. Papers of the international workshop $8^{\text {th }}$-9th April 2009, Istanbul. Menschen-Kulturen-Traditionen 1. Rahden/Westfahlen. Leidorf. 83-94.

Garfinkel Y. 1987. Burnt lime products and social implications in the PPNB villages of the Near East. Paléorient 13(1): $69-76$.

Herling L., Kasper K., Lichter C. and Meriç R. 2008. Im Westen nichts Neues? Ergebnisse der Grabungen 2003 und
2004 in Dedecik-Heybelitepe. Istanbuler Mitteilungen 58 : $13-65$.

Horejs B. 2012. Çukuriçi Höyük. A Neolithic and Bronze Age Settlement in the Region of Ephesos. In M. Özdoğan, N. Başgelen (eds.), Neolithic in Turkey: New Excavations and New Research. Arkeoloji ve Sanat Yayınları. İstanbul: 117-131.

Isaakidou V. 2008. The fauna and economy of Neolithic Knossos revisited. In V. Isaakidou, P. Tomkins (eds.), Escaping the Labyrinth: The Cretan Neolithic in Context. Oxbow Books. Sheffield: 95-112.

Kansu Ş. 1963. Ege (̇̇mir) Alt Paleolitiğine ait ilk not. Belleten 27: 485-490.

1969. İzmir dolaylarında bulunan ikinci bir Alt Paleolitik alete ait not. Belleten 129: 79-80.

Kartal M. 2003. Anatolian Epi-Paleolithic Assemblages: Problems, Suggestions, Evaluations and Various Approaches. Anadolu/Anatolia 24: 45-62.

2009. Türkiye'de Son Avcr-Toplayncılar. Arkeoloji ve Sanat Yayınları. İstanbul.

Martinoli D. 2004. Food plant use, temporal changes and site seasonality at Epipaleolithic Öküzini and Karain B Caves, Southwest Anatolia, Turkey. Paléorient 30(2): 6180 .

Otte M., Yalçınkaya I., Leotard J.-M., Kartal M., Bar-Yosef 0., Kozlowski J., López-Bayón I. and Marschack A. 1995. The Epi-Paleolithic of Öküzini cave (SW Anatolia) and its mobiliary art. Antiquity 69(266): 931-944.

Ottoni C. and 36 authors 2013. Pig domestication and human-mediated dispersal in Western Eurasia revealed through ancient DNA and geometric morphometrics. Journal of Molecular Biology and Evolution 30(4): 823-832.

Özbaşaran M. 2003. Aşıklı-Musular ilişkisinde kireç taban11 yapılar. In M. Özdoğan, H. Hauptmann and N. Başgelen (eds.), From Villages to Towns: Studies presented to Ufuk Esin. Arkeoloji ve Sanat Yayınları. İstanbul: 361-372.

Özdoğan M. 2011. Archaeological Evidence on the westward expansion of farming communities from Eastern Anatolia to the Aegean and the Balkans. Current Anthropology 52(4): 415-430.

Perlès C. 2001. The Early Neolithic in Greece. Cambridge University Press. Cambridge.

Reingruber A. 2011. Early Neolithic settlement patterns and exchange networks in the Aegean. Documenta Praehistorica 38: 291-305. 
Roosevelt C. H., Luke C. 2010. Central Lydia Archaeological Survey: 2008 Results. Araştırma Sonucları Toplantısı 27: $1-24$.

Russell N. 2006. Çatalhöyük worked bone. In I. Hodder (ed.), Changing Materialities at Catalhöyük: Reports from the 1995-99 Seasons. McDonald Institute for Archaeological Research. Cambridge: 339-357.

Sağlamtimur H. 2007. Ege Gübre Neolitik Yerleşimi. In M. Özdoğan, N. Başgelen (eds.), Türkiye'de Neolitik Dönem. Yeni Kazılar, Yeni Bulgular. Arkeoloji ve Sanat Yayınlar1. İstanbul: 373-376.

2011. Environmental Factors in the Neolithic Settlement of Ege Gübre. In R. Krauß (ed.), Beginnings... new research in the appearance of the Neolithic between Northwestern Anatolia and the Carpathian Basin. Papers of the international workshop $8^{\text {th }}$-9th April 2009, Istanbul. Menschen-Kulturen-Traditionen 1. Verlag Marie Leidorf GmbH. Rahden/Westfahlen: 77-82.

2012. The Neolithic Settlement of Ege Gübre. In M. Özdoğan, N. Başgelen (eds.), Neolithic in Turkey: New Excavations and New Research. Arkeoloji ve Sanat Yayınları. İstanbul: 117-131.
Sampson A. 2005. New evidence from the early productive stages in the Aegean basin from the $9^{\text {th }}$ to $7^{\text {th }}$ millennium BC. In C. Lichter (ed.), How did farming reach $\mathrm{Eu}$ rope? BYZAS 2. Ege Yayınları. İstanbul: 131-141.

Scheu A., Geörg C., Schulz A., Burger J. and Benecke N. 2012. The arrival of domesticated animals in South-Eastern Europe seen from Ancient DNA. In E. Kaiser, W. Schier and J. Burger (eds.), Population dynamics in Pre- and Early History. New Appraoches by Stable Isotopes and Genetics. Walter de Gruyter. Berlin/Boston: 45-54.

Scheu A., Bollongıno R., Vıgne J.-D., Tresset A., Çakırlar C., Benecke N. and Burge J. in prep. The arrival of domesticated cattle in Europe - an ancient DNA perspective.

Strasser T., Panagopoulou E., Runnels C., Murray P. M., Thompson N., Karkanas P., McCoy F. W. and Wegmann K. W. 2010. Stone Age Seafaring in the Mediterranean. Evidence from the Plakias Region for Lower Paleolithic and Mesolithic Habitation of Crete. Hesperia 79: 145-190.

Zvelebil M. 2001. The Agricultural Transition and the Origins of Neolithic Society in Europe. Documenta Praehistorica 28: 1-26. 